\title{
The Impact of Motivation on Dynamic Capabilities in Jordanian Commercial Banks
}

\author{
Ayman Suliman Jarrar ${ }^{1}$ \\ ${ }^{1} \mathrm{PhD}$ researcher, The World Islamic Science \& Education, Jordan \\ Correspondence: Ayman Suliman Jarrar, PhD researcher, The World Islamic Science \& Education, Jordan.
}

Received: September 21, 2020

Accepted: December 7, 2020 Online Published: December 28, 2020

doi:10.5539/ibr.v14n1p130

URL: https://doi.org/10.5539/ibr.v14n1p130

\begin{abstract}
This paper aims to identify the impact of motivation on dynamic capabilities. The study population consists of all workers in the 13 Jordanian commercial banks, listed in Amman Stock Exchange which is estimated by 20,000 workers. The sample size is 384 sample entails in Jordanian commercial banks. the study results indicate that there is a significant impact of the motivation dimensions on the managerial dynamic capabilities. This study has some limitations which includes data access limitations and access limitations. The study recommends extending its scope and review the human resources polices to review the motivation system in the Jordanian banks.
\end{abstract}

Keywords: dynamic capabilities, motivation, Jordanian banks

\section{General Framework}

\subsection{Overview}

The organizations operate in a dynamic business environment, and they pay considerable efforts to attain the competitive advantage as one of the main objectives and key challenges of them at the same time (Girod and Whittington, 2017). Several organizations distinguish this fact as they desire to survive in their aggressive industry. Thus, sensing, seizing, exploiting the market needs is an engine to the organization to create new avenues and opportunities in a proactive manner (Gomez et al., 2015). The literature that supported the dynamic managerial capabilities is lead Teece (2014) and Barney (1991, 2001, 2016). Such literature focuses on the recognition of market opportunities based on the manager's previous knowledge, their social networks, environmental analysis, and internal capabilities analysis which led by the managers with dynamic capabilities (Schilke, 2014; Teece, 2018).

The Jordanian commercial banks considered to be one of the main drivers for the economy in Jordan, it plays the role of money multiplier by accepting deposits and trust funds from groups of people and re-distribute those funds again for qualified investors. The small size of the Jordanian economy and the heightened competition between the Jordanian banks has forced the managers to focus on developing their resources and capabilities to be able to respond to different environmental challenges. It has become apparent that ordinary and operational resources at the base level are no more sufficient to compete in a given market or industry and achieve a sustainable competitive advantage (Winter, 2003). Therefore, the need arises for the next level of capabilities which can be divided into micro-foundations and higher-order capabilities. The micro foundation capabilities involve adjustments and recombination of ordinary capabilities while the higher-order capabilities by which management senses new opportunities for the future, seize new or changing opportunities, and determines the best configuration for the organization (Teece, 2018).

In order to realize the organizational goals, they ought to heavily rely on their workforce to be efficient, effective, dedicated and stay motivated (Bawa, 2017). Enhancing the workers' motivation is a crucial issue, and area of concentration to authors and academics. Workers who have low motivation levels are expected to focus less on their responsibilities, avoid their liabilities, avoid the support of their managers. They may leave their job (Bawa, 2017; Porter, Riesenmy \& Fields, 2016). On the other hand, motivated workers tend to be innovative, loyal, productive as well (Porter et al., 2016).

The motivation has resulted in rich publications that support in understanding employee's expectations, beliefs and objectives in the professional path and the literature always valuated the motivate across them (Bawa, 2017). 
Identifying the drivers that impact motivation behaviour is one of the biggest challenges faced by organizations (Sulaiman et al., 2014). Several motivational theories discussed to justify the indirect or the direct influence of the motivation (Sulaiman et al., 2014; Porter et al., 2016).

One of the methods to recreate and extend and upgrade dynamic capabilities is through staffing, training and development and developing employee's awareness how to contribute in building competitive advantage (Johnson, Whittington, Scholes, Angwin and Regnér, 2017). Still, the mean stream of the motivation theories depends on the Western viewpoints of needs. Thus, this study will provide an empirical study from the Middle East and investigate the impact of the needs of achievement motivation theory can help in building dynamic capabilities.

\subsection{Research Problem}

Dynamic capabilities in Jordanian commercial banks is their ability to renew and recreate their resources and capabilities to meet the demands of their changing environment, the threshold resources and capabilities those needed by Banks to compete in the market can barely provide competitive parity, while distinctive resources and capabilities can provide competitive advantage which might be temporary. Therefore, long term and sustainable competitive advantage can only be achieved through building dynamic capabilities through developing the three generic types of dynamic capabilities (sensing, seizing, and reconfiguring) which can be acquired or developed internally or externally through outsourcing.

The dynamic capabilities have micro foundations in people behavior within the organizations such as how decisions are made, personal relationships, beliefs and entrepreneurial skills and culture within an organization. Therefore, this study will examine the building of dynamic capabilities in the Jordanian commercial banks withs its dimensions (Sensing, Seizing and reconfiguring) and the impact of motivation with its dimensions "Need for achievement, Need for power and Need for affiliation" on building the dynamic capabilities in Jordanian commercial Banks. According to the above, the research question can be phrased as follows:

What is the Impact of Motivation on Dynamic capabilities in the Jordanian commercial banks?

\subsection{Research Importance}

Even that the motivation is not a contemporary issue to management literature, however, it is still resulting in many academic publications and empirical research due to its value and contribution to the organizational success, employee's performance, and employee's attuited. Further, the extents of motivation correlate with building the dynamic capabilities in the Jordanian commercial banks as per the context of this study. The theoretical position of this research is in responding to the gaps in the literature and recommendations shaped by researchers about the future research concerning the variables of interest, namely, motivation, and dynamic capabilities. For instance, the study of Pett and Wolff (2017) stated that future studies ought to expand on their work by including other regions and different countries rather than the USA because the self-motivation and dynamic capabilities topic is comparatively new given the recent regionalization across many countries, especially in the emerging markets. Also, they recommended to use other instruments and approach as they applied their study on the SMEs.

The study of Marques, Marques, Ferreira \& Ferreira (2019). Also confirmed the need of applying their study on other countries and institutions rather than the hospitals in Portugal. Accordingly, this study will improve the knowledge about the dynamic capabilities and if it is affected by the motivation. Up to researcher's limits of knowledge, this study will be a pioneer study that will investigates the same topic in Jordan, so, it will help future research to enrich the academic work in Jordan as it will be a baseline to their work. Further, it will contribute to the strategic management literature and the organization behavior literature as it will clarify if employee motivation is one of the main determinants to building Dynamic capabilities in organizations.

The practical importance of this research is in the prospects of management leadership in the Jordanian commercial banks of using the outcome of this research to understand the significance role of motivation on the performance and productivity of employees and how this can be attributed to building the dynamic capabilities that is needed by managers to achieve a sustainable competitive advantage. Accordingly, it will motivate the managers in the banking sector to pay more attention, preserve the equality and expand the spending on the motivation programs, which can be by promotion, pay, recognition or even training, as this will lead managers to build and expand dynamic capabilities which can sense, seize and reconfigure the resources they have in support of the banks. Thus, attain better performance, competitive advantage, and sustainability. 


\section{Literature Review and Hypothesis Development}

\section{- The Meaning of Motivation}

The "word motivation was coined from the Latin word "movere" that means to run. Also, it is involved with why people perform in specific ways. Thus, motivation is a fuel that drives people to accomplish their aims and objectives. In truth", without these fuels, humans will be indolent (Deci \& Ryan, 2010). In this understanding, motivation is not what the company does to workers but preferably the urge that issues from the worker (Byars \& Rue, 2002; Deci \& Ryan, 2010). The company simply requires generating the conditions or setting that would cause out motivation.

Many modern authors have further defined the concept of motivation. Generally, it is defined as a driving force that initiates and directs behavior. In other words, Anderman, 2020 said that the "motivation is a kind of internal energy which drives a person to do something in order to achieve something".

Boachie-Mensah (2006) referred to motivation as "the willingness of an individual to respond to organizational requirements in the short run. He further pointed out that motivation causes people to make choices from the available alternatives, about how best to allocate their energy and time".

Kreitner \& Kiniciki, (2006) "Motivation is further defined as the psychological process that causes the arousal, direction and persistence of voluntary actions that are goal directed" (Kreitner \& Kiniciki, 2006). Daft (2006) the motivation is "an internal force but also external or both forces that trigger actions that persist until a certain goal is achieved. A goal is the satisfaction of a need or needs and this need is the difference between the desired state and the actual state".

Staff motivation "has shifted crucial to employee behavior, including loyalty, engagement and job performance" (Bateman \& Snell 2007). Motivation is defined as "those internal and external forces that trigger actions that persist until a certain goal is achieved" (Daft, 2006). In business, these triggers of behavior are different needs that workers are attempting to satisfy through different intrinsic and extrinsic rewards they get at work (Acquah, 2017). Ryan \& Deci (2010) registered that feelings of support and feelings of freedom must co-occur to achieve high levels of intrinsic motivation.

\section{- Achievement Motivation Theory}

The concept of achievement in terms of motivation was from Atkinson (1964) as referenced by Acquah, 2017 who defined it "as the comparison of performances with others and against certain standard activities". "Accomplishment motivation is a drive to excel in learning tasks combined with the capacity to experience tried in accomplishment". McClelland and Atkinson were the leading scholars to focus on the achievement motivation context. For McClelland, Atkinson and for the study of Clark and Lowell, (1953), which is also referenced by Acquah, 2017 "people strive for perfection in a field to achieve and not for some reward are supposed to have a great need for achievement. These needs have been identified as n-achievement for convenience".

Anderman, 2020 recommended that achievement motivation is a compound of two personality variables: the tendency to approach success and the tendency to avoid failure. Biegge and Hunt (1980) as referenced by Acquah, 2017 defined achievement motivation as "the drive to work with diligence and vitality, to always steer toward targets, to obtain dominance in challenging and challenging tasks and create a sense of achievement as a result". This description entails three elements: the stimulations of personal abilities, consistent struggles with drive and obtaining of a feeling of satisfaction.

\section{- Need for Achievement}

McClelland et al. (1958) "explained the need for achievement as the master in competition with exceptional standards of excellence". This meaning presupposes that the goals of an individual is to be victorious in terms of racing with some example of excellence. The person may fail to accomplish this goal, but the concern over the specification of quality yet permits one to identify the purpose required as an attainment goal. Acquah, 2017 "described that competitions with a pattern of excellence were most striking when an individual was in immediate struggle with somebody else". However, "it can additionally be apparent in the concern for how well one individual completes a task, irrespective of how a name else is making. It can be understood from the various interpretations that workers with high-level achievement needs seek to do extremely well in their work and enjoys the recognition of their efforts. They attend to avoid situations where there is only a small gain while also withdrawing high-risk situations where negligence is a possibility".

\section{- $\quad$ Need for Power McClelland (1961)}

The Need for Power is defined as the need for power as a "concern with the control of the means of influencing a 
person" (p. 167). Lussier and Achua (2007) defined it as "the unconscious concern for influencing others and seeking positions of authority" (p. 42). Further, Daft (2008), stated that the need for power "is the desire to influence or control others, being responsible to others, and having authority over others".

Naturally, "people who demonstrate the need for power have a passion for being influential and require to create an impact. McClelland maintained that a person's need for power is one of two characters, namely, individual and institutional. Those who require personal power want to lead others. Persons who want institutional power (i.e., social power) want to make the efforts of others to promote the goals of an organisation. Supervisors with a great need for functional power tend to be more efficient than these with a high need for personal power" (Acquah, 2017).

\section{- Need for Affiliation}

McClelland (1961) "stated that the need for affiliation is establishing, maintaining, or restoring a positive affective relationship with another person and this relationship is most adequately described by the word friendship" (p. 160). Therefore, "the need for affiliation is the unconscious concern for developing, maintaining, and restoring close personal relationships" (Lussier \& Achua, 2007, p. 43). Daft (2008) "defined the need for affiliation as the desire to form close personal relationships, avoid conflict, and establish warm friendships" (p. 233)". (Okorley, 2010) "added in "individuals who demonstrate the need for affiliation are seeking interactions with other people and are social".

\section{- Managerial Dynamic Capabilities}

In the last few decades, field specialists, researchers, experts, and academics have laid marvelous efforts in introducing and investigating the managerial dynamic capabilities as a quite modern concept in the strategic management field. They have landed on one ground when they come to agree on a standardized baseline of it. It was defined as a set of abilities that can assess the managers to invent, amend and then extend the ways in which organizations making improve (Teece, 2018). Accordingly, the dynamic capabilities are stress on demonstrating the creation of competitive advantage by effectively sensing, reading, analyzing, exploiting and adapting to the dramatically changing business environments. In other simpler words, organizations that have managers with noticeable dynamic capabilities will feel conspicuous changes in the quality of decisions, the realism of strategic changes implementation, and the boosting in the organizational performance (Barney, 2017).

Reading and understanding the environmental dynamism and overall directions is not an option anymore to those who wish to survive and grow. Thus, organizations need to draw their long-term strategies about the stability and the growth in terms of customers, market share, profitability, and expansion options. The internationalization is one of the majorly followed strategies due to many drivers including; markets similarities, liberalization, governmental, de-regulation, cost or competitiveness drivers (Dodgson, 2018). Furthermore, any organization can access international markets by one of four methods; exporting, franchising, whole owned subsidiary, or by joint ventures. Regardless of the elected motive and method, the organization shall critically evaluate and assess its internationalization readiness from a comprehensive standing point before proceeding on (Rosnan and Abdullah, 2018).

Historically, the dynamic managerial capabilities were originally obtained and derived from the resource-based view introduced by Barney in 1990s. Consequently, many researchers supported the assumption of the independent distribution of abilities and resources across organizational progress and equilibrium (e.g. Barney, 2001; Helfat and Peteraf, 2009). Following that, the dynamic capabilities view has divided into many areas over sorts of literature, the most well-known are the areas that emphasized on the process-oriented approach (e.g. Eisenhardt and Martin, 2000), the outcome-oriented approach (e.g. Teece et al. 1997) and then the resource reconfiguration approach (Peteraf et al., 2013).

As an extraordinary turning point, Teece, (2007) settled great works to develop the dynamic capabilities by combining them with a specific consequence like the prediction of a positive correlation between the of dynamic capabilities and competitive advantage actualization, besides the organizational success.

The most recently empirical evidence turned the studies to the application of "dynamic capabilities-based theory" in the multinational enterprise context (Teece, 2009). Yet, in 2018 types of research, the dynamic capabilities are yet a trending researching topic that is highly correlated to organizational change and strategic leadership.

In the same general frame, it is important to distinguish between the "ordinary" and the "dynamic" capabilities. The ordinary capabilities are mainly intended to permit the production of traditional and traditional products and services. Such abilities could be each owned or outsourced. The ordinary abilities originate from the skilful employment and assets in the business, compressing; the human capital, the processes, the plants, the intangible assets. Besides, they 
cover the regulatory systems, compressing; the coordination to combine outside and in-house resources, the extent of knowledge in finishing the defined tasks. However, these capabilities would nevermore target the organizational growth or responses to any volatility in the market.

The managers' and enterprises' dynamic capabilities help their organizations to govern the methods which they build, integrate, and reconfigure the external and internal competencies to address all planned and unintended changing in the business environments (Sako and Chondrakis, 2017). The dynamic capabilities also come as a part of the managerial proficiencies of reading the environment and then developing the matching business models which, in turn, will address new opportunities and avoid threats. Basically, having promised and sturdy dynamic capabilities define the organizational capacity to adapt, innovate, and respond to the customer needs to have the advantage over rivals (Gomez et al., 2015).

Sensing, seizing, exploiting, and then turning the market gaps and needs into opportunities are highly influenced by the entrepreneurs and managers alertness to discover these chances in a proactive manner. These abilities are part of the "managerial dynamic capabilities" (Schilke, 2014). Many supportive debates in the same frame mentioned that the opportunities could not only be found, yet they are created. These academic debates also investigated more on how the entrepreneurialism and innovation can be originated, altered or customized to access new markets and nations (Teece, 2014). Also, it was settled that the creation and the recognition of market opportunities rely on the entrepreneur's individual traits including; the owned previous knowledge, the social networks, and finally the entrepreneurial own competences to understand the market alerts (Shane, 2000).

Lakew, Woretaw, Tsega (2020) aimed to investigate the impact of the reward practices on the employees' motivation who works in the banking sector in Ethiopia. The study sample entailed Bank of Abyssinia and Abay Bank in South Gondar Zone. The reward practices were operationalized as the benefit, benefit, training and working condition. Therefore, a self-administered questionnaire was used to collect the responses from a random sample of 203 respondents based on a Multistage sampling method. The result of the multiple regression variables showed that the recognition and the training and the payment have positive and significance on employee's motivation as the rf-value was significant and the model justified around $64 \%$ based on the $\mathrm{R}^{2}$ value.

Alhamadi (2020) tried to explain the influence of dynamic capabilities on organization performance in Qatar's ministry of finance. A complete census method used to collect data from top management of Qatar's ministry of finance. 160 respondents were administered through structured questionnaire. Data was analyzed through structural equation modeling (SEM). The findings of the study found that there is statistically significant influence of dynamic capabilities with its dimension sensing, seizing, and reconfiguring on organization performance. The researcher recommends that motivating employees to share knowledge to improve their work methods that would increase productivity and performance. The researcher also recommends managers to develop their employee's abilities to sense the changes in the environmental by providing proper training. In addition, the researchers recommend in future studies to expand the population of the study into other countries and populations and different business sectors to be able to generalize the findings. Finally, the researcher recommends examining the impact of dynamic capabilities on other dimensions other than organization performance as a competitive performance, innovation, behavior, and organization ambidexterity.

Abazeed (2020) investigated the Impact of strategic capabilities on organizational ambidexterity as one of the critical concerns to the banking sector. The population of this study entails 200 managers who work in Jordanian commercial banks. The return was 168 responses ( $84 \%$ return rate). For the data analysis, the study applied the SEM technique to test the main and sub hypotheses. The study result pointed out that the knowledge management mediates the association between the managerial, strategic capabilities and the organizational ambidexterity. Further, the strategic capabilities have a statistical impact on both knowledge management $(\mathrm{r}=$; Sig. $=0.000)$. Last, the researchers recommend to decision-makers in the commercial banks to shed light ion the development of the strategic managerial capabilities.

Sattar, Ullah, Qasim and Warraich (2019) aims at presenting the theoretical and empirical evidence of the employees' motivation in the banking sector as a sample from Multan city in Pakistan. The study applied the quantitative research design and adopted a cross-sectional survey that was distributed to a random sample of 362 employees. The main findings figured out that job enrichment is the highest influential factor in increasing employees' motivation. Still, the quality of the work-life was negatively influencing the motivation.

Bilginoglu and Yozgat (2018) investigated the association between knowledge management and human resources management. The study as well investigated the moderating role of the perceived training intensity, the knowledge sharing and the motivation. The study sample entailed 497 employees who are hired in private, public, foreign capital and participation banks operating in Turkey. The results indicated a positive relationship between the 
perceived training intensity and knowledge sharing. Further, it provides the moderating role of motivation and self-efficacy.

Adegboyega (2018) investigated the influence of achievement motivation on Nigerian undergraduates' attitudes towards examination. 1536 undergraduates were administered through purposive and stratified sampling technique, data was collected through two questionnaires, achievement motivation scale (AMS) and attitude toward examination scale (ATES). Data was analyzed through Pearson product moment correlation (PPMC) statistical technique at $\mathrm{P} \leq 0.05$ and the findings $[\mathrm{r}=.55, \mathrm{df}=1534$, Siq. $=0.000]$ showed that majority of Nigerian undergraduates have high level of achievement motivation, in addition the Nigerian undergraduates showed positive attitude toward examination and there was a significant correlation between need for achievement motivation and attitude of Nigerian undergraduates toward examination.

Sabiu, Abdullah, Amin, and Tahir (2018) examined the correlation between the need for achievement motivation and entrepreneur persistence of bumiputra entrepreneurs in Malaysia. 171 questionnaires were self -administered through simple random sampling technique to micro bumiputra entrepreneurs, the results from Pearson correlation was $(\mathrm{r}=0.527$, Sig. $=0.000, \mathrm{P} \leq 0.05)$ which showed that there is evidence that there is statistically significant correlation between the need for achievement motivation and entrepreneur persistence with a positive upward linear relationship between motivation and entrepreneur persistence with strong correlation. The study recommends in the future that the focus of government programs and initiatives should be on the quality of the entrepreneurs and not on the quantity.

- Research Hypotheses

According to the context of this research, below is the research hypothesis.

- $\mathrm{H}_{1}$ : There is no statistically significant impact at $\mathrm{p} \leq 5 \%$ of Motivation with its dimensions ("Need for Achievement, Need for Power, Need for Affiliation") on Dynamic Capabilities with its combined dimension (Sensing, Seizing, Reconfiguring) in Jordanian Commercial banks.

- $\mathrm{HO}_{2}$ : There is no statistically significant impact at $\mathrm{p} \leq 5 \%$ of Motivation with its combined dimensions ("Need for Achievement, Need for Power, Need for Affiliation") on Sensing in Jordanian Commercial banks.

- $\mathrm{H}_{3}$ : There is no statistically significant impact at $\mathrm{p} \leq 5 \%$ of Motivation with its combined dimensions ("Need for Achievement, Need for Power, Need for Affiliation") on Seizing in Jordanian Commercial banks.

- $\mathrm{HO}_{4}$ : There is no statistically significant impact at $\mathrm{p} \leq 5 \%$ of Motivation with its combined dimensions ("Need for Achievement, Need for Power, Need for Affiliation") on Reconfiguring in Jordanian Commercial banks.

\section{Methodology}

This research is explanatory, it will apply the quantitative method and follow the deductive approach as the data will be attained based on the questionnaire instrument.

\subsection{Research Population and Sample}

The population of the research consists of all workers in the 13 Jordanian commercial banks, listed in Amman Stock Exchange, namely, the Housing Bank, Cairo Amman Bank, Arab Bank, Invest bank, Union Bank, ABC bank, Capital bank, Jordan bank, Jordan Kuwaiti Bank, Jordan Ahli bank, Commerrital bank, Arab Jordan Investment Bank and Société Générale bank. The number of workers in the banks is estimated by 20,000 workers. According to the population size (10593) divided on the selected banks and depending on Sekaran`s table (Sekaran, 2013), the sample size was determined based on the employees` number in each selected bank. The current study will use simple random sampling method. The sample size is 384 , and the valid for analysis is 336 respondents. Depending on the sampling size of (Sekaran, 2013).

\subsection{Measurement Instruments}

The measurement items were adopted from previous literature to affirm on the validity and reliability of the scales, the study will contain 4 main parts as the following:

- $\quad$ Part (1): The Demographic data that includes the gender, the age, the position and the year of experience of the respondent. 
- Part (2): The measurement scale of managerial capabilities and its dimension of sensing, seizing and reconfiguring that was adapted based on the study of Garrido et al., 2020.

- Part (3): The measurement scale of the motivation and its dimensions (need of achievement, need of power and need of affiliation) that was adapted based on the study of Andersen, 2018

The questionnaire will be transcribed in English and then interpreted into Arabic to widen the segment of respondents. All items were rated as a five-point Likert scale as follows for positive questions: " $(5)=$ very important, (4) = Important, (3) = for Neither Important nor Unimportant, (2) = Unimportant, (1) = Very Unimportant".

\subsection{Research Model}

In the light of the research hypothesis, figure (1) illustrates the research model.

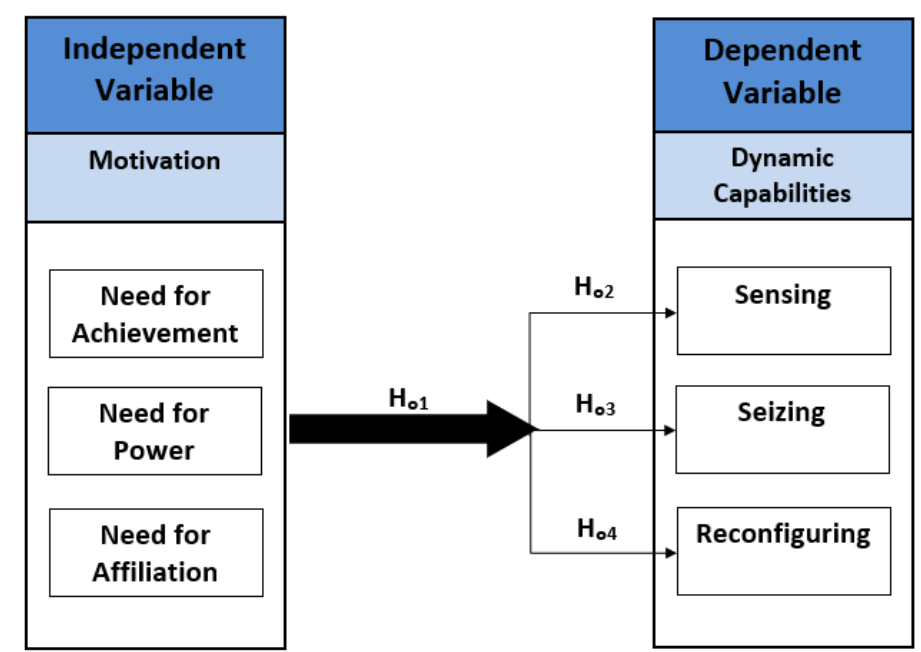

Figure 1. The Impact of Motivation on Dynamic Capabilities in Jordanian Commercial Bank (Teece, 2009; Pardee, 1990)

\section{Data Analysis}

Table 4.1 shows the results of the demographic data for the respondents; before that, it is worth to mention that the final sample size is 336 respondents. Nevertheless, the researcher distributed a total of 602 surveys using both online and paper-based questionnaires. The number of the returned instruments was 492 (81.7\% return rate). After eliminating any incomplete or inappropriately filled questionnaires, the valid ones were 336 (55.8\% of the total), which is the decent rate in comparison with the lengthy approvals and authorization process followed by the researcher to distribute and share the survey to the targeted bankers.

Table 4.1. Demographic Data

\begin{tabular}{|l|l|l|l|}
\hline & & Frequency & \% \\
\hline \multirow{4}{*}{ Gender } & Male & 143 & $42.6 \%$ \\
\cline { 2 - 4 } & Female & 193 & $57.4 \%$ \\
\hline \multirow{5}{*}{ Educational Level } & Under 30 years & 104 & $31.00 \%$ \\
\cline { 2 - 4 } & $30-39$ years & 136 & $40.50 \%$ \\
\cline { 2 - 4 } & $40-49$ years & 69 & $20.50 \%$ \\
\cline { 2 - 4 } & $50-59$ years & 24 & $7.14 \%$ \\
\cline { 2 - 4 } & Over 60 years & 3 & $0.80 \%$ \\
\cline { 2 - 4 } & High School & 4 & $1.2 \%$ \\
\cline { 2 - 4 } & College Degree & 23 & $6.8 \%$ \\
\cline { 2 - 4 } & Bachelor's degree & 254 & $75.6 \%$ \\
\cline { 2 - 4 } & Master's Degree & 53 & $15.8 \%$ \\
\cline { 2 - 4 } & Doctoral Degree & 2 & $.64 \%$ \\
\hline \multirow{5}{*}{ Experience in Banking } & Less or equal 9 years & 132 & $39.2 \%$ \\
\cline { 2 - 4 } & $10-14$ years & 63 & $36.0 \%$ \\
\cline { 2 - 4 } & $15-20$ & $18.8 \%$ \\
\hline
\end{tabular}




\begin{tabular}{|l|l|l|l|}
\hline & More than 20 & 20 & $6.0 \%$ \\
\hline \multirow{5}{*}{ Job Position } & Basic - level staff & 70 & $20.8 \%$ \\
\cline { 2 - 4 } & Basic- level Manager & 99 & $29.5 \%$ \\
\cline { 2 - 4 } & Middle- level Manager & 133 & $39.6 \%$ \\
\cline { 2 - 4 } & High- level Manager & 32 & $9.5 \%$ \\
\cline { 2 - 4 } & Other & 2 & $0.6 \%$ \\
\hline
\end{tabular}

As observed from the results in table 4.1, the males are 143, which represent $42.6 \%$ of the research sample. However, the females are 193, which represent $57.4 \%$ of it. These results from statistical viewpoint show diversity in the research sample and proper representation of each gender, which, in turn, helps to generalize the results from the sample to the bankers as the research population as both genders are well signified. On the other hand, the results show an issue in gender equality in the banking industry as the higher representation of the female employees in the banks.

For the age groups, most of the sample fall in the groups $30-39$ years $(40.5 \%)$, and under 30 years $(31 \%)$, these groups as well represent most of the bankers. The results are confirmed from the years of experience where about $39.2 \%$ of the sample (i.e., the majority) are experienced with less or equal nine years, followed by $36.0 \%$ for the category $10-14$ years. However, the last group is $6.0 \%$ for the senior people with more than 20 years of experience. The years of expertise are coherent with the organizational structure, where the operational levels require junior, senior and administrative employees. However, the executive level is filled with the least number of employees who involves in decision-makers and strategic planning matters.

It is also observed from the academic qualification that the massive of the respondents hold a bachelor degree as per the required job qualification for most of the positions in the banks, their percentage is $75.6 \%, 15.8 \%$ of them holds Master's degree, and $6.8 \%$ holds a diploma and $1.2 \%$ has a high school degree. Last, the managerial positions show that there is a diversity in the views, where the mid-level managers are $39.6 \%$ of the sample, the basic level managers are 29.5\%, the nonmanagerial employees (Basic - level staff) are 20.8\%. Last, the executive level people are $9.5 \%$ of the sample.

\section{- $\quad$ Normality Test}

The outcomes of Skewness test are $-1.806,-1.774,-1.501,-1.402,-1.697,-1.238,-1.271,-1.376,-1.417,-1.415$, -0.253 and -1.565 respectively, where all of the values are within the cutoff point acceptance range $(-2-+2)$. The Kurtosis tests results are 5.090, 5.280, 4.682, 3.364, 5.661, 2.241, 2.320, 2.996, 3.503, 3.286, -1.100 and 4.631 , all the variables fall in the range in of the cutoff points $(-7$ to +7$)$.

The results settle the capability to generalize the research verdicts and conclusions from the sampled bank employees across all other employees in the banking sector as they are normally distributed.

\subsection{Reliability Test}

The "purpose of the reliability test is to examine the supposition that if the researcher distributes the same instrument (questionnaire) instrument to the same respondents within almost the same time and conditions, then check whether the researcher will obtain the same outcomes or not. Statisticians evaluate the reliability using Cronbach Alpha coefficient. Its value is recommended to exceed 0.7, yet some academics accept the values 0.6 and 0.5" (Sekaran \& Bougie, 2013).

Table 4.3. Cronbach alpha

\begin{tabular}{|c|l|}
\hline & Cronbach Alpha \\
\hline Need of achievement & 0.959 \\
\hline Need of power & 0.884 \\
\hline Need of affiliation & 0.897 \\
\hline Sensing & 0.887 \\
\hline Seizing & 0.871 \\
\hline Reconfiguring & 0.910 \\
\hline
\end{tabular}

Table 4.3 demonstrates high-reliability values as all dimensions and variables are higher than the hypnotized cutoff point of 0.7 . The results bring high creditability to the results and ability to generalize the conclusions of the sample to the whole population (whole banking sector employees) as they reflect high credibility and honesty in the answers. 


\section{- Hypothesis Testing}

The research will apply the "multiple regression" using SPSS (as test step 1). In the multiple regression, the "correlation coefficient" as one of the commonly referred statistical tests which assess to determine the direction and the strength of this relationship between any two variables. Pearson correlation coefficient ( $r$ ) ranges between the values -1 to the value +1 . However, the "zero" value means non-existence of any linear relationship. The values of 1.00 and -1.00 figures out a complete full direct correlation (positive/negative) between these variables (Hair et al., 2011). The data normality (see section 4.2) and multicollinearity (see section 4.6) are preconditions of the linear regression (Hair et al., 2011).

The Coefficient of Determination $\left(\mathrm{R}^{2}\right)$ measures how much the independent variable(s) justifies and clarify the research problem, which is the dependent variables. Coefficient of Determination - $\mathrm{R}^{2}$ value falls between zero and one. The higher the coefficient of determination values means an improved regression model and better fit based on the responses (observations) (Salkind, 2016). The F-value reveals the impact of the independent.

Table 4.3. Multiple regression

\begin{tabular}{|c|c|c|c|c|}
\hline & & $\begin{array}{l}\text { T-Test } \\
<2\end{array}$ & $\begin{array}{l}\text { P value } \\
<\mathbf{5 \%}\end{array}$ & B (beta) \\
\hline \multicolumn{5}{|c|}{ Managerial Dynamic capabilities } \\
\hline - $\quad$ Need of achievement & & 3.035 & 0.003 & 0.476 \\
\hline - $\quad$ Need of power & & 11.808 & 0.005 & 0.094 \\
\hline - $\quad$ Need of affiliation & & 8.801 & 0.000 & 0.155 \\
\hline $\mathbf{R}$ & 0.854 & & & \\
\hline R Square & 0.730 & & & \\
\hline F-value & 449.081 & & & \\
\hline$P$ value & 0.000 & & & \\
\hline
\end{tabular}

According to results in table 4.3 , the $\mathrm{r}$ value is $85.4 \%$ which specifies a strong relationship, the $\mathrm{R}^{2}$ value as well designates the examined dimensions can justify $73 \%$ of the performance which means a strong model fitting based on the research unit. For the impact test, the F-value (449.081) of the scenario shows an impact of the general model motivation and managerial Dynamic capabilities. This is confirmed with the p-value of the F-test $(0.000)$. The $t$-test as a specific test shows a significant impact as well where the p-value is less than $5 \%$. For the innovation, the highest T-value is illustrated (26.427) and the p-value is significant as well. The impact is significant as well for the relationships between the motivation and managerial dynamic capabilities

The beta values designate if the independent variable or dimension increase with one measurement unit, the $\beta$ value confers the resulted increase (if $\beta$ is positive) or the reduction (if $\beta$ is negative) on the managerial dynamic capabilities.

\section{Limitations}

This study has some limitations which includes data access limitations and access limitations. The study recommends extending its scope and review the human resources polices to review the motivation system in the Jordanian banks.

\section{Conclusions}

The motivation issue has been subjects of significant interest across management researchers and managers at the same level, and it has resulted in many theories by academics. The motivation is the way individuals and groups are inspired to act in a predictable manner with the view to get a positive reward and to satisfy real human needs to stay motivated and to act beyond a call of duty. The motivation leads the employees to perform in a level that is above the expectations under the "wants" not the "must" motives. Different kinds of motivations can involve a person. These consist of primary/necessary and consequent motivation. Primary motivation entails need such as starvation, thirst, warmth, sex, and other primary motives which influence a person's behavior at a fundamental level. The secondary motivation is recognized in therapy as "learned" motivation, varies from one personality to another. Hereabouts, a person consciously craves a goal or result and works in a way that causes.

The managerial implications of this research is to reflect on the management experience to improve the way that the firms improve their team members from the perspective of senior management and strategic perspective. Further, this study is customized to the context of banking sector, which brings improved empirical results. 
The dynamic capabilities are essentially emphasized on three key elements which are identification of the environment, developments of the internal capabilities. Also, the evaluation of all opportunities and their relation to customers' requirements as part of "sensing" the unexplored futures. The mobilization of resources to approach these opportunities, and then "seizing" the benefit of them. Furthermore, the "reconfiguring" of these scrutinized values. Thus, sensing, seizing, and reconfiguring are important steps for any organization that wants to sustain long-term directions with consumers' needs. Moreover, responding to external environment (social, technologic, ecological, economic, political (STEEP)) factors without neglecting the rivals and the competitive forces.

The study sample entailed 336 employees where a survey instrument distributed to them, the study results indicate that there is a significant impact of the motivation dimensions on the managerial dynamic capabilities.

\section{References}

Adegboyega, L. O. (2018). Influence of Achievement Motivation on Nigerian Undergraduates' Attitude towards Examination. International Journal of Instruction, 11(1), 77-88. https://doi.org/10.12973/iji.2018.1116a

Alhamadi, M. S. (2020). The Influence of Dynamic Capabilities on Organisational Performance: An Empirical Study on Qatar's Ministry of Finance. Global Journal of Management And Business Research.

Anderman, E. M. (2020). Achievement motivation theory: Balancing precision and utility. Contemporary Educational Psychology, 101864. https://doi.org/10.1016/j.cedpsych.2020.101864

Barney, J. B. (2001). Is the resource-based "view" a useful perspective for strategic management research? Yes. Academy of management review, 26(1), 41-56. https://doi.org/10.5465/amr.2001.4011938

Barney, J. B., \& Mackey, A. (2016). Text and metatext in the resource-based view. Human Resource Management Journal, 26(4), 369-378. https://doi.org/10.1111/1748-8583.12123

Barney, J., Wright, M., \& Ketchen Jr, D. J. (2001). The resource-based view of the firm: Ten years after 1991. Journal of management, 27(6), 625-641. https://doi.org/10.1177/014920630102700601

Bawa, P., Watson, S. L., \& Watson, W. (2018). Motivation is a game: Massively multiplayer online games as agents of motivation in higher education. Computers \& Education, 123, 174-194. https://doi.org/10.1016/j.compedu.2018.05.004

Boachie-Mensah, F. O. (2006). Essentials of management.

Girod, S. J., \& Whittington, R. (2017). Reconfiguration, restructuring and firm performance: Dynamic capabilities and environmental dynamism. Strategic Management Journal, 38(5), 1121-1133. https://doi.org/10.1002/smj.2543

Gomez, C., Perera, B. Y., Weisinger, J. Y., Tobey, D. H., \& Zinsmeister-Teeters, T. (2015). The impact of immigrant entrepreneurs' social capital related motivations. New England Journal of Entrepreneurship, 18(2), 3. https://doi.org/10.1108/NEJE-18-02-2015-B002

Haarhaus, T., \& Liening, A. (2020). Building dynamic capabilities to cope with environmental uncertainty: The role of strategic foresight. Technological Forecasting and Social Change, 155, 120033. https://doi.org/10.1016/j.techfore.2020.120033

Hasbullah, R., \& Moeins, A. (2017). The influnceof professionalism, achievement motivation and empowerment against the work discipline and its implication on teacher performance: empirical study on high school teachers in Karawang regency. International Journal of Business and Commerce, 5(6), 18-36.

Johnson, G., Whittington, R., Scholes, K., Angwin, D. N., \& Regnér, P. (2017). Exploring strategy (No. 11th e). Pearson.

Marques, C. S., Marques, C. P., Ferreira, J. J., \& Ferreira, F. A. (2019). Effects of traits, self-motivation, and managerial skills on nursing intrapreneurship. International Entrepreneurship and Management Journal, 15(3), 733-748. https://doi.org/10.1007/s11365-018-0520-9

Naguib, A. N., Elsaid, E., \& Elsaid, A. M. (2017). The Impact of Dynamic Capabilities on Sustainable Competitive Advantage in the Pharmaceutical Sector in Egypt. Business and Management Research, 6(2), 1. https://doi.org/10.5430/bmr.v6n2p1

Omollo, P. A., \& Oloko, M. A. (2015). Effect of motivation on employee performance of commercial banks in Kenya: A case study of Kenya Commercial Bank in Migori County. International journal of human resource studies, 5(2), 87-103. https://doi.org/10.5296/ijhrs.v5i2.7504

Osisioma, H., Nzewi, H., \& Mgbemena, I. (2016). Dynamic capabilities and performance of selected commercial 
banks in Awka, Anambra State, Nigeria. European Journal of Business and Social Sciences, 4(10).

Pardee, R. L. (1990). Motivation Theories of Maslow, Herzberg, McGregor \& McClelland. A Literature Review of Selected Theories Dealing with Job Satisfaction and Motivation.

Pett, T. L., \& Wolff, J. A. (2017). Exploring competitive strategies: the role of managerial perceptions and motivations on internationalisation of SMEs. International Journal of Entrepreneurial Venturing, 9(2), 181-202. https://doi.org/10.1504/IJEV.2017.086484

Porter, T. H., Riesenmy, K. D., \& Fields, D. (2016). Work environment and employee motivation to lead. American Journal of Business. https://doi.org/10.1108/AJB-05-2015-0017

Ramsay, J. E., Pang, J. S., Ho, M. H. R., \& Chan, K. Y. (2017). Need for power predicts career intent in university students. Journal of Career Assessment, 25(3), 389-404. https://doi.org/10.1177/1069072716639690

Sabiu, I. T., Abdullah, A., Amin, A., \& Tahir, I. M. (2018). An empirical analysis of the need for achievement motivation in predicting entrepreneurial persistence in Bumiputra entrepreneurs in Terengganu, Malaysia. International Journal of Business and Globalisation, 20(2), 190-202. https://doi.org/10.1504/IJBG.2018.089867

Sabti, A. A., Md Rashid, S., Nimehchisalem, V., \& Darmi, R. (2019). The Impact of Writing Anxiety, Writing Achievement Motivation, and Writing Self-Efficacy on Writing Performance: A Correlational Study of Iraqi Tertiary EFL Learners. SAGE Open, 9(4), 2158244019894289. https://doi.org/10.1177/2158244019894289

Singh, B., \& Rao, M. K. (2016). Effect of intellectual capital on dynamic capabilities. Journal of Organizational Change Management. https://doi.org/10.1108/JOCM-12-2014-0225

Sulaiman, M., Ahmad, K., Sbaih, B., \& Kamil, N. M. (2014). The perspective of Muslim employees towards motivation and career success. e-Bangi, $11(1)$.

Teece, D. J. (2009). Dynamic capabilities and strategic management: Organizing for innovation and growth. Oxford University Press on Demand.

Teece, D. J. (2018). Business models and dynamic capabilities. Long range planning, 51(1), 40-49. https://doi.org/10.1016/j.lrp.2017.06.007

Winter, S. G. (2003). Understanding dynamic capabilities. Strategic management journal, 24(10), 991-995. https://doi.org/10.1002/smj.318

\section{Copyrights}

Copyright for this article is retained by the author(s), with first publication rights granted to the journal.

This is an open-access article distributed under the terms and conditions of the Creative Commons Attribution license (http://creativecommons.org/licenses/by/4.0/). 